
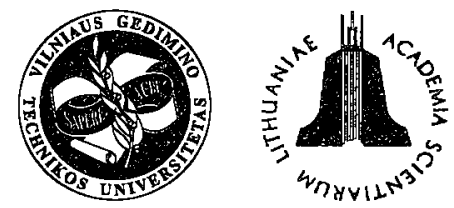

ISSN 1648-4142 TRANSPORT

http:/www.vtu.lt/english/editions

\title{
MOTIVATIONS AND BENEFITS OF ISO SYSTEM IMPLEMENTATION IN TRANSPORTATION-RELATED COMPANIES: MARKETING ASPECT OF ISO
}

\author{
Laima Ivanauskienè, Sigitas Urbonavičius \\ Marketing Department of Vilnius University, \\ Saulètekio al. 9, LT-2040 Vilnius, Lithuania. Tel (370) 52366148 , \\ E-mail: sigitas.urbonavicius@iti.lt
}

Received: 200305 29; accepted 20031114

\begin{abstract}
The paper analyses the effects of ISO system implementation and certification. It separately reviews motivations to implement ISO system and benefits after the system implementation. The authors analyse motivations and benefits that are internal (managerial) and external (mainly - marketing type). The analysis is performed on the basis of the survey of Lithuanian companies, comparing findings with similar research in other countries. Industry (sectorial) specifics is analysed on the basis of transportation-related companies group.
\end{abstract}

Keywords: ISO system, marketing aspect of ISO, transportation-related companies.

\section{Introduction}

ISO is a series of international standards that sets the requirements and recommendations for the quality of management systems. The essential part of requirements refers to regulations how management operations shall be conducted. However, ISO system has a broad set of influence on business operations, generating numerous internal and external effects to the companies. Internal effects mainly refer to changes in management procedures, quality improvements, cost savings, increase of efficiency and profitability. External effects group includes company relationships with its partners: clients (most often) and suppliers (sometimes). Though both groups are heavily interrelated, some companies tend to seek more for internal, some others - for external effects (benefits) implementing ISO systems. The group of internal effects is analyzed much more frequently and significantly deeper, since it represents the main objective for ISO system development in general. The second group, which deals with less straightforward and mainly marketing-related effects, is much less analyzed. This paper analyzes both internal and external effects, separately discussing the motivations and benefits of ISO certification. The analysis is based on the opinions of Lithuanian companies' managers. The opinions are compared with sectors and with similar studies abroad.

Another aspect of analysis and discussion is related to transport (transportation) industry specifics. Authors try to differently define a transportation-related sector, in addition to transportation companies including com- panies that deal with transportation indirectly, i.e. create required infrastructure or provide maintenance services. The article argues that such a definition can be proven, since managers of the newly defined group express relatively consistent opinions that differ from the evaluations of manufacturing companies or service companies - at least in discussion about ISO. Also, their managers have rather consistent and specific opinions about the marketing aspect of ISO.

\section{Background}

Since ISO series of standards sets out the requirements for management systems, its basic task is to ensure conformance to specification in any procedure in the company. In a broader sense, ISO standards seek to ensure that suppliers design, create and deliver products and services, which meet standards and specifications, thus preventing non-conformity [1]. In addition to this, ISO is a historical development from simpler forms of quality management and a certain step moving towards TQM (Fig 1).

Worldwide statistics for ISO systems implementation shows rather steady growth of a number of certified companies (Fig 2).

Business world becoming more and more global, some country (regional) specifics remains to be important. In case of Central and Eastern Europe this is mainly related to known historical events and changes of both political and economic systems. Lithuania represents a 


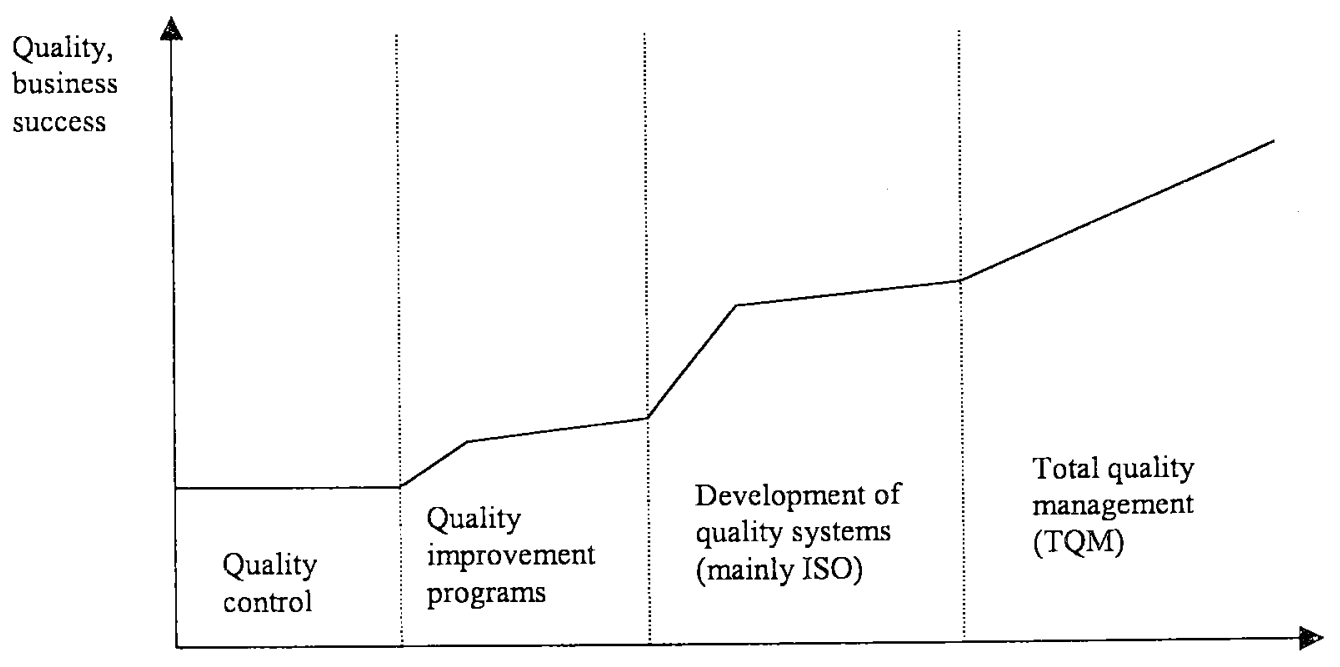

Fig 1. Efficiency of quality management methods [2]



Fig 2. Number of certified systems in the world [3]



Fig 3. Number of certified ISO systems in Lithuania

rather typical case in this respect, showing late start and rapid growth of the number of implemented ISO systems. The trend in Lithuania shows a process that is clearly accelerating (Fig 3 ).

There are little trends yet noticeable in the structure of Lithuanian certified companies population. However, approximately two-thirds of certified companies represent the sector that joins services and trade (mainly wholesale), which well enough reflects the development of business in Lithuania in general (Fig 4).

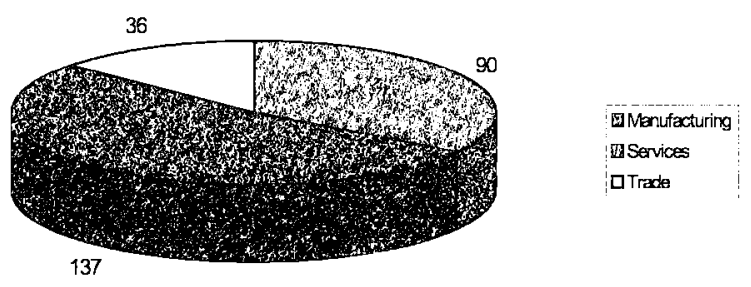

Fig 4. Distribution of certified companies in Lithuania by sector

\section{Objectives}

Despite being directed to improve managerial procedures, ISO systems go beyond this and serve as a significant marketing tool for companies. Managers declare this during interviews and in many other occasions, but more systematic analysis would be required whether external (marketing) motivations are the driving motivations to start ISO system implementation, or marketing benefits of ISO are noticed by managers only after the system implementation.

Also, though there are natural differences in sector specifics, managers of various businesses might have similar or different motivations and experience both similar and different effects from ISO system implementation. Therefore a sectorial aspect of analysis is required.

In addition to traditional division between manufacturing and service businesses the authors decided to separate out businesses that are directly or indirectly 
linked with transportation. Under such definition, a transportation-related sector included transportation and logistics companies, tourist agencies, road construction companies as well as car and truck repair and maintenance service providers. Though being different, all these businesses have some common characteristics: they heavily depend on local and international transportation flows of goods and people, are dependant or involved in the development of local transportation infrastructure and related services. Transportation itself is always seen as a rather complex system that has an aspect of network activities optimization $[4,5]$, and also is closely related with infrastructure development, for example, road construction [6]. Their belongingness to the same business group would be even more justified if managers of these companies show similar opinions about important business development tools, such as ISO.

\section{Research}

The questionnaire was developed by modifying similar research tools used by Francis Buttle in the United Kingddom (1997); as well as by Carmen Escaniano, Esteban Fernandez and Camilo Vasquez in Spain (2001). Both of them analyzed the motives and benefits of ISO certification. The Lithuanian questionnaire differs from the two by more numerous and detailed questions about marketing-related aspects of ISO certification and includes adjustments of formulations according to the management opinions expressed in interviews before the survey.

General population of ISO certified Lithuanian companies at the end of 2002 included 263 companies. Certified transportation-related businesses represent $8 \%$ of the total number and $12 \%$ of service companies. The objective to disclose this sector specifics required better representation of transportation-related companies in the sample and predetermined the method of sampling in general. A judgmental sample was drawn to select respondents from various industries, paying specific interest to companies that are directly involved in transporta- tion or that can be considered as influencing transportation infrastructures. Questionnaires were mailed to 70 pre-selected companies. Reminding follow-up phone calls allowed to achieve very high response rate, equal to $68,6 \%$ and have a total sample of 48 companies, which equaled to $18,25 \%$ of the total population.

The sample included $33,3 \%$ of companies involved in manufacturing, 39,6\% - in various services, and 27,1\% of transportation-related companies. There was almost equal distribution of companies by the number of employees into categories $11-50,51-100,101-250$, and more than 251 , just one company representing category below 10 . By turnover, $50 \%$ of represented companies belonged to the group that generates 5-25 million Litas (EUR 1,5-7,5) annual sales.

\subsection{General Findings}

The first goal was to analyze motives of Lithuanian companies to implement ISO systems and to receive certification. The literature review, discussions with consultants and company managers identified 10 major motives for ISO system implementation and certification. Respondents were asked to grade each of these motives based on their company specifics, using Likert rating scale, ranging from: $1=$ no importance to $5=$ very important motive.

The most important motives, reaching the mean of evaluations above 4 included: a) willingness to improve consistency of functions within company, to increase efficiency, and b) to improve product quality. None respondent ranked any of these motives 1 , and standard deviation in ranking these two motives was the lowest, which tells about the uniformity of very high valuation among all the respondents. Both motives are of internal nature, i.e. mainly directed towards the improvements within the company. However, all the nearest following motives were external, leaving other two internal motives at the very bottom of ranking (Table 1 ).

Table 1. Rankings of Lithuanian companies' motives to implement ISO systems

\begin{tabular}{|c|c|l|c|c|c|c|}
\hline No & I/E & MOTIVES & Min & Max & Mean & $\begin{array}{c}\text { Std. } \\
\text { Deviation }\end{array}$ \\
\hline 1 & I & Improve consistency of functions within company, increase efficiency & 2 & 5 & 4,52 & 0,77 \\
\hline 2 & I & Improve product quality & 2 & 5 & 4,31 & 0,83 \\
\hline 3 & E & Increase competitiveness & 2 & 5 & 3,92 & 0,94 \\
\hline 4 & E & Help in maintaining/increasing market share & 1 & 5 & 3,83 & 1,06 \\
\hline 5 & E & ISO certificate is required when company participates in tenders & 1 & 5 & 3,69 & 1,42 \\
\hline 6 & E & ISO certificate could be used as a promotional tool & 1 & 5 & 3,50 & 1,07 \\
\hline 7 & E & Increase of export potential & 1 & 5 & 3,50 & 1,47 \\
\hline 8 & I & Cost reduction & 1 & 5 & 3,50 & 1,27 \\
\hline 9 & E & Customer pressure & 1 & 5 & 2,48 & 1,24 \\
\hline 10 & I & Provides proof of commitment to TQM & 1 & 5 & 3,42 & 1,30 \\
\hline
\end{tabular}


External motives are lead by two interrelated motives of increasing competitiveness and maintaining/increasing market share, pushing more concrete motive of tender requirement below them. Another very concrete and often in interviews mentioned motive of customer pressure was ranked the lowest among all the external motives.

The second goal was to analyze the benefits of ISO certification and to relate them to ranking of motives. The benefits of certifications were also analyzed on the basis of a list, identified on the basis of literature review, discussions with consultants and company managers. The list included 17 most often used benefits. Respondents were asked to grade each of these benefits based on their company specifics, using Likert rating scale, ranging from: $1=$ no benefit to $5=$ very important benefit.

Again, two top rankings are given to the most traditional internal benefits of ISO system implementation. Both of them fully correspond two most important motives for certification, and it is possible to conclude that two main expectations of ISO implementation are met.

However, next evaluations are less correlated with the sequence of motives ranking (Table 2).

It seems that many managers have discovered how well it can be used as a marketing/promotional tool or how helpful it is in tenders only after ISO system implementation. In general, the correlation between the evaluation of motives and benefits is close to 0,7 and can be evaluated as very strong. At the same time, the correlation between ranking of internal and external motives is lower than between ranking internal and external benefits $(0,396$ and 0,572 respectively). This means that managers were driven by a few motives, but have dis- covered more numerous and intermixed effects of certification. Also, motives seem to be better understood and higher evaluated (average rank 3,67 ) than benefits (average rank 3,04). This might mean that in some cases ISO certification effects do not meet expectations of managers.

\subsection{Comparison with Findings in Other Countries}

Findings of this survey can be compared with the results obtained in other countries just to a limited extent due to methodological differences. However, some important observations can be made.

The analysis of ISO implementation motivations disclosed the importance of such internal motives as willingness to improve consistency of functions within company, to increase efficiency and to improve product quality. These are very similar with findings in Spain in 2001, but significantly differ from the results of earlier studies in the UK and Sweden, where such external factor as customer pressure was identified as a major driver to have ISO [7].

The most important external motivations for Lithuanian companies included increasing competitiveness and support in maintaining/increasing market share. This differs both from the findings in Spain and in the UK, since Spanish companies expected to use ISO certificate for improving company image [8], and UK ones - anticipating demand from future consumers for ISO.

In general, Lithuanian companies were driven by internal motives, followed by a relatively general motive of competitiveness that integrates internal and external aspect. Spanish companies were similarly consid-

Table 2. Rankings of Lithuanian companies' benefits of ISO systems

\begin{tabular}{|c|c|c|c|c|c|c|}
\hline No & $\mathrm{I} / \mathrm{E}$ & BENEFITS & Min & Max & Mean & $\begin{array}{c}\text { Std. } \\
\text { Deviation }\end{array}$ \\
\hline 1 & I & Clearer procedures, improved management control & 1 & 5 & 4,40 & 0,89 \\
\hline 2 & I & Quality improvements & 1 & 5 & 3,73 & 0,89 \\
\hline 3 & $\mathrm{E}$ & The certificate is used as a promotional tool & 1 & 5 & 3,56 & 1,22 \\
\hline 4 & $E$ & Reduction of client complaints and environmental damage & 1 & 5 & 3,52 & 0,99 \\
\hline 5 & $\mathrm{E}$ & The certificate helps to win tenders & 1 & 5 & 3,40 & 1,44 \\
\hline 6 & $\mathrm{I}$ & Improved efficiency & 1 & 5 & 3,06 & 1,16 \\
\hline 7 & $\mathrm{E}$ & Help in retaining Lithuanian clients & 1 & 5 & 3,02 & 1,21 \\
\hline 8 & $\mathrm{I}$ & Increase in employee loyalty, motivation and reduction of turnover & 1 & 5 & 2,94 & 1,04 \\
\hline 9 & $\mathrm{I}$ & Improved profitability & 1 & 5 & 2,88 & 1,16 \\
\hline 10 & $E$ & Increased sales in foreign markets & 1 & 5 & 2,77 & 1,39 \\
\hline 11 & $\mathrm{E}$ & Help in retaining foreign clients & 1 & 5 & 2,75 & 1,47 \\
\hline 12 & $\mathrm{E}$ & Attracted new clients abroad & 1 & 5 & 2,75 & 1,44 \\
\hline 13 & $\mathrm{I}$ & Cost reduction & 1 & 5 & 2,71 & 1,22 \\
\hline 14 & $\mathrm{E}$ & Help in increasing sales to existing clients abroad & 1 & 5 & \begin{tabular}{|l|}
2,69 \\
\end{tabular} & 1,39 \\
\hline 15 & $E$ & Help in increasing sales to existing clients in Lithuania & 1 & 5 & 2,67 & 1,15 \\
\hline 16 & $E$ & Increased sales in Lithuania & 1 & 4 & 2,60 & 1,01 \\
\hline 17 & $E$ & Attracted new clients in Lithuania & 1 & 5 & 2,29 & 1,11 \\
\hline
\end{tabular}


ering improving product quality and improving internal processes and procedures as the main drivers. However, Spanish companies were much more oriented towards answering demands from the environment (improving company image, requisite to compete in the sector, anticipate market trend). UK companies were even more oriented towards environmental pressure, and four of the six most important motives relate to external (marketing) aspects (anticipated demand from customers, market share improvement, customer pressure, use of ISO as a promotional tool).

Surveys also disclose differences in perceptions of ISO implementation benefits in various countries.

The most important benefits for Lithuanian companies include clearer procedures, improved management control as well as overall improvement of quality. However, in the UK study the most valued benefits are related to profitability, then - to process improvements, and after that - to marketing benefits.

Spanish companies rank better understanding of processes and responsibilities as the most important benefit (the same as Lithuanian), but improved products/services quality is just in the fourth place, allowing external (marketing) benefit of image improvement take the second position. Remarkable that sales increase, market share increase and exports increase are the least ranked

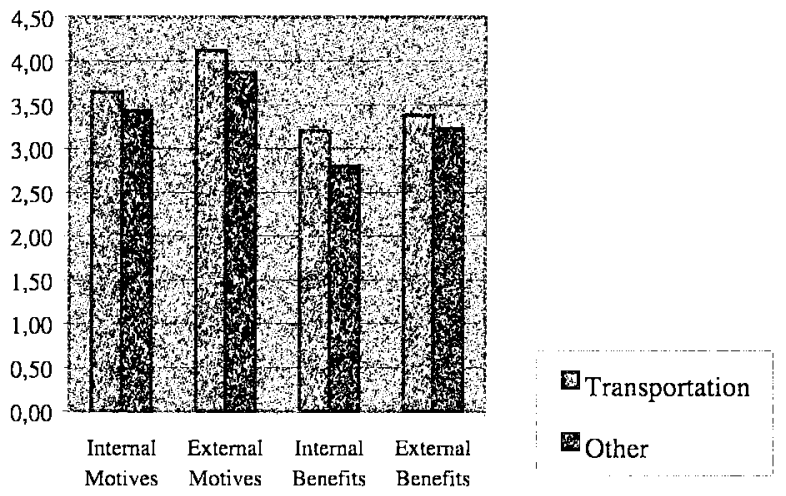

Fig 5. Average rankings benefits in Spain, whereas in Lithuania similarly formulated benefits take much higher places.

Spanish survey results are similar to Lithuanian ones in one inieresting aspect: in both countries companies rank motives (expectations) higher than benefits (results). This might show that managers' overestimation of ISO benefits is not specific to Lithuania only.

\subsection{Specifics of Transportation-related Business}

Transportation-related companies have some specifics, which have been reflected comparing them with manufacturing companies as well as with other service companies.

First of all, transportation-related companies ranked both motives and benefits higher than all other companies (Fig 5).

Transportation-related companies also to some extent differ from the rest in prioritizing some certification motives. While there are no differences in sequence of 5 most important motives, among others, transport-related companies put cost reduction much higher than others (Table 3).

Evaluating ISO benefits, transportation-related companies pay much less attention to the reduction of client complaints and environmental damage and towards the increase in employee loyalty, motivation and reduction of turnover. Instead, they are better noticing ISO benefits in helping to increase sales to existing clients abroad and retaining existing foreign clients in general (Table 4).

In general, there are noticeable differences how manufacturing, service and transportation-related companies evaluate ISO motives and benefits. This is best noticeable in Stem-and-Leaf plots, where median is shown in two central quartiles, together with minimum and maximum evaluations within each group of respondents.

Evaluating internal motives of ISO system, transport-related companies show less consistent evaluations

Table 3. Rankings of Lithuanian transportation-related companies' motives to implement ISO systems

\begin{tabular}{|c|c|l|c|c|c|c|}
\hline No & I/E & MOTIVES & Min & Max & Mean & Std. Deviation \\
\hline 1 & I & Improve consistency of functions within company, increase efficiency & 2 & 5 & 4,77 & 0,83 \\
\hline 2 & I & Improve product quality & 3 & 5 & 4,31 & 0,85 \\
\hline 3 & E & Increase competitiveness & 2 & 5 & 4,15 & 1,14 \\
\hline 4 & E & Help in maintaining/increasing market share & 2 & 5 & 4,15 & 0,90 \\
\hline 5 & E & ISO certificate is required when company participates in tenders & 2 & 5 & 3,85 & 1,21 \\
\hline 6 & I & Cost reduction & 1 & 5 & 3,77 & 1,17 \\
\hline 7 & E & ISO certificate could be used as a promotional tool & 2 & 5 & 3,77 & 1,30 \\
\hline 8 & E & 1 & 5 & 3,62 & 1,66 \\
\hline 9 & I & Proverease of export potential proof of commitment to TQM & 2 & 5 & 3,62 & 1,26 \\
\hline 10 & E & Customer pressure & 1 & 5 & 2,31 & 1,32 \\
\hline
\end{tabular}


Table 4. Rankings of Lithuanian transportation-related companies' benefits of ISO systems

\begin{tabular}{|c|c|c|c|c|c|c|}
\hline No & $\mathrm{I} / \mathrm{E}$ & BENEFITS & Minimum & Maximum & Mean & $\begin{array}{c}\text { Std. } \\
\text { Deviation }\end{array}$ \\
\hline 1 & & Clearer procedures, improved management control & 2 & 5 & 4,46 & 0,97 \\
\hline 2 & & Quality improvements & 2 & 5 & 4,08 & 1,04 \\
\hline 3 & & The certificate is used as a promotional tool & 2 & 5 & 4,00 & 1,15 \\
\hline 4 & & The certificate helps to win tenders & 2 & 5 & 3,92 & 1,12 \\
\hline 5 & & Help in retaining Lithuanian clients & 1 & 5 & 3,62 & 1,26 \\
\hline 6 & & Reduction of client complaints and environmental damage & 2 & 5 & 3,38 & 0,96 \\
\hline 7 & & Improved efficiency & 1 & 5 & 3,31 & 1,18 \\
\hline 8 & & Help in increasing sales to existing clients abroad & 1 & 5 & 3,23 & 1,59 \\
\hline 9 & & Help in retaining foreign clients & 1 & 5 & 3,23 & 1,59 \\
\hline 10 & & $\begin{array}{l}\text { Increase in employee loyalty, motivation and reduction of } \\
\text { turnover }\end{array}$ & 1 & 5 & 3,00 & 1,08 \\
\hline 11 & & Increased sales in foreign markets & 1 & 5 & 2,92 & 1,50 \\
\hline 12 & & Improved profitability & 1 & 5 & 2,92 & 1,19 \\
\hline 13 & & Increased sales in Lithuania & 1 & 4 & 2,85 & 1,21 \\
\hline 14 & & Attracted new clients abroad & 1 & 5 & 2,85 & 1,68 \\
\hline 15 & & Help in increasing sales to existing clients in Lithuania & 1 & 5 & 2,77 & 1,48 \\
\hline 16 & & Cost reduction & 1 & 5 & 2,54 & 1,13 \\
\hline 17 & & Attracted new clients in Lithuania & 1 & 4 & 2,46 & 1,27 \\
\hline
\end{tabular}

than two others, with relatively wider overall spread of central group of opinions. This might be a reflection of differences among companies that in the current research were defined as 'transport-related'. Opinions of service companies' managers are the most consistent but also the lowest both in terms of median and overall distribution (Fig 6).

In the evaluation of external motives, all three groups of respondents showed more consistent opinions, and the central group of answers within transportation-related companies group was equally well concentrated as within others. However, transport-related companies evaluated the importance of external motives closer to manufacturers, than to service companies (Fig 7).

Three analyzed groups are the most uniform in evalu-



Fig 6. Internal motives evaluation by three groups ating the internal benefits of ISO system implementation. Medians of all groups' answers are very close, just evaluations of manufacturing companies are less spread in terms of minimum and maximum values (Fig 8).

And finally, transport-related companies are the most enthusiastic about the external benefits of ISO system implementation. With the highest minimum and maximum values as well as with higher median this group is noticeably above others (Fig 9).

High evaluation of the external benefits by transport-related companies shows that these companies discover more external benefits of ISO system implementation than manufacturing or service companies. Perhaps this can be related to the fact that transportation activities are often international by their content and the

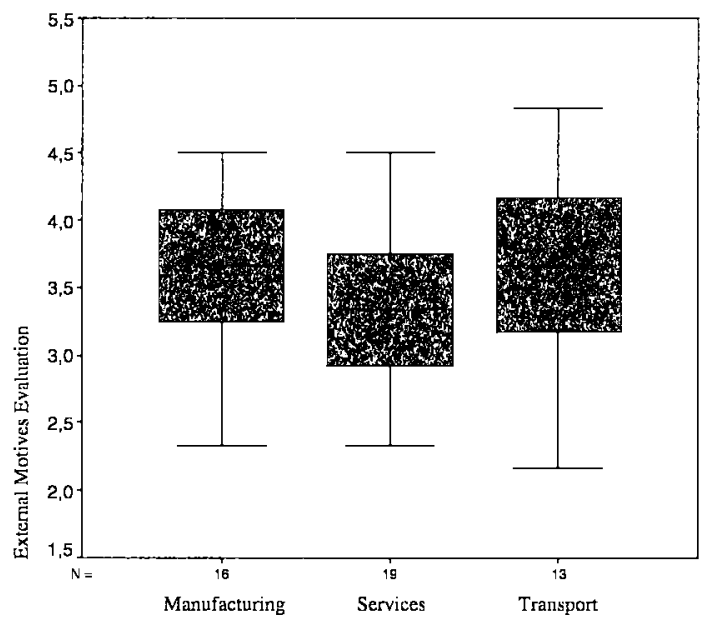

Fig 7. External motives evaluation by three groups 


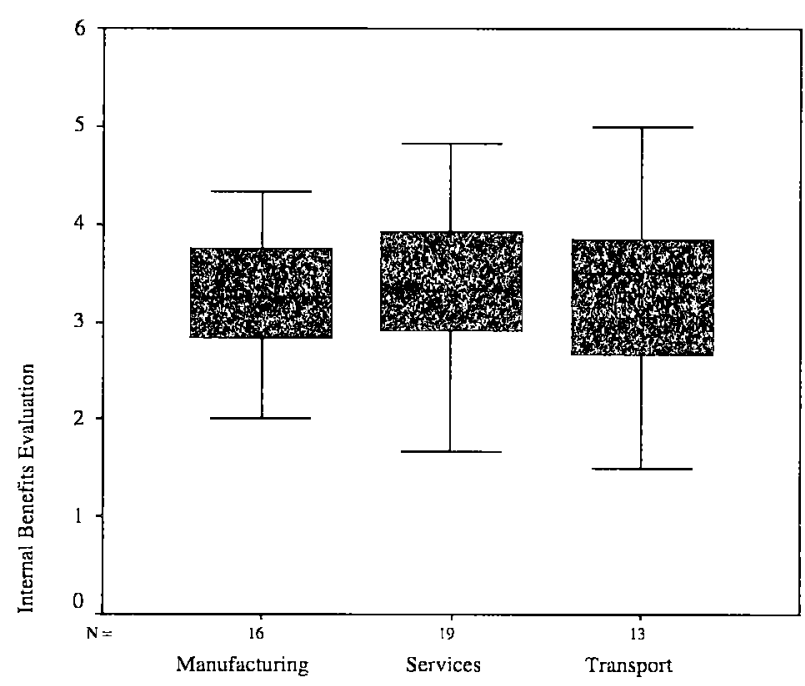

Fig 8. Internal benefits evaluation by three groups

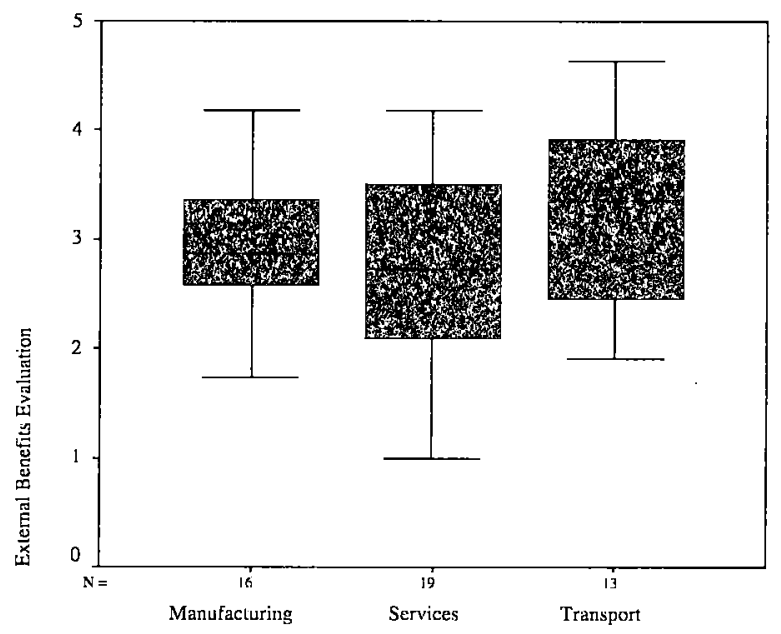

Fig 9. External benefits evaluation by three groups

recognition of ISO certificate is more expected from foreign environments, where ISO concept is better known historically. Nevertheless, this also proves that Lithuanian transportation-related companies are able to better use ISO certificate in marketing than others.

\section{Conclusions}

Many previous studies in many countries show that most often the main driver for ISO system implementation certification is environmental pressure. At the same time, benefits of its implementation are to a large extent linked with the reduction of this pressure. However, it has been observed that Lithuanian experience has some specifics.

The number of ISO certified companies increases in Lithuania with significant acceleration. Major motivations for implementing ISO are internal, related to the most traditional objectives of ISO: functions consistency, efficiency, product quality. External (marketing) motivations are rather important, but direct pressure from customers is ranked the lowest among all external motives.

Lithuanian companies are experiencing expected managerial benefits of ISO implementation (clearer procedures, better management control) and quality improvements. In addition to this, many important (though less expected) marketing benefits occur: companies use ISO as a promotional tool in general, or specifically in tenders, apply it for developing or maintaining market share, exports.

The idea to separate out a group of transportationrelated companies proved to be logical, since sectorial similarities of these companies resulted in specific opinions about ISO motives and benefits. Transportationrelated companies seem to be more optimistic in both evaluations and in many cases they are more oriented to external factors than others. It seems that this group better notices and uses marketing benefits of ISO certification than others.

\section{References}

1. Buttle, F. ISO 9000: marketing motivations and benefits. International Journal of Quality \& Reliability Management, 14, 9, 1997, p. 993-947. Internet -http:// www.emeraldinsight.com/ijqrm.htm. 2002 March 2.

2. Ruževičius, J.; Adomaitienè, R. Intemationalisation of quality and methodological questions. Economics and Management (Ekonomika ir vadyba). Kaunas: Technologija, 1999. 301 p. (in Lithuanian).

3. The ISO Survey:twelfth cycle (2002) highlights. http://www.iso.ch/iso/en/iso $9000-14000 / \mathrm{pdf} /$ survey 12thcycle.pdf. Internet 2003 September 5.

4. Vasiliauskas, A. V. Modelling of freight flows that consist of multiple products transported by different models of transport in a multimodal network. Transport, Vol XVII, No 5, Vilnius: Technika, 2002, p. 194-200.

5. Vasiliauskas, A. V. Modelling of intermodal freight transportation network. Transport, Vol XVII, No 2, Vilnius: Technika, 2002, p. 117-121.

6. Maitra, B.; Azmi, M.; Ibrahim, S. N. Priotization of road projects - a disutility based approach. Transport, Vol XVII, No 2, Vilnius: Technika, 2002, p 52-56.

7. Carlsson, M. and Carlsson, D. Experiences of implementing ISO 9000 in Swedish industry. International Journal of Quality and Reliability Management, 13, 7, 1996, p. 3647. Internet - http://www.emeraldinsight.com/ijqrm.htm. 2002 March 2.

8. Escanciano, C.; Fernandes, E.; Vazciuez, C. ISO 900 Certification and quality management in Spain: results of a national survey. The TQM Magazine, 2001, 3, p. 192-200. 